\title{
Simulation and Optimization of the VTC200C Machining Center Production Plan
}

\author{
Marian Králik, Vladimír Jerz \\ Institute of Manufacturing Systems, Environmental Technology and Quality Management, Faculty of \\ Mechanical Engineering, Slovak University of Technology in Bratislava, Námestie slobody 17, \\ 81231 Bratislava, Slovak Republic
}

\begin{abstract}
The paper describes the use of the Plant Simulation software to create a simulation model of the manufacturing process in the VTC200C machining centre. A genetic algorithm was used to optimize the production process. It is an algorithm that learns itself and looks for the best solution based on input data. The optimization is done based on the assessment of the output data from the simulation model. Based on the results of the optimization, a more efficient production plan was designed in the selected company.
\end{abstract}

Keywords - simulation, optimization, machining centre, production plan, Plant Simulation

\section{Introduction}

The material flow and process efficiency can be achieved by optimization methods and simulation models. The simulation models can detect inefficient locations and operations in the manufacturing process immediately at the design stage [1], [2].

The paper describes the use of the Plant Simulation software to create a simulation model of the manufacturing process in the VTC200C machining center.

DOI: 10.18421/TEM93-59

https://doi.org/10.18421/TEM93-59

Corresponding author: Marian Králik,

Faculty of Mechanical Engineering, Slovak University of Technology in Bratislava, Námestie slobody 17, 81231 Bratislava, Slovak Republic.

Email: marian.kralik@stuba.sk

Received: 07 July 2020.

Revised: 15 August 2020.

Accepted: 20 August 2020.

Published: 28 August 2020.

(cc) BY-NC-ND (C) 2020 Marian Králik \& Vladimír Jerz; published by UIKTEN. This work is licensed under the Creative Commons Attribution-NonCommercial-NoDerivs 4.0 License.

The article is published with Open Access at www.temjournal.com
A genetic algorithm was used to optimize the production process [7], [8]. It is an algorithm that learns itself and looks for the best solution based on input data.

The optimization is done based on the assessment of the output data from the simulation model. Based on the results of the optimization, a more efficient production plan was designed in the selected company.

\section{Description of the Current Status}

The company produces components in a production hall in several machining centers simultaneously. The machining centers are spread over the hall and do not create a production line. The production plan is set for a given period of time and the production should take as short time as possible. Each machining center has its own production plan consisting of several series of workpieces and must be observed during production. When starting production with the use of multiple machining centers at the same time, a problem occurs during the tool replacement process, due to same tools used in multiple machining centers simultaneously. The MATRIX system registers the movement and status of the tools that are in the warehouse, but MATRIX cannot tell where the tool is located. It records only the time when the tool was removed from the warehouse. There may occur a situation when the tool does not return back to the warehouse though it is needed for the next product manufacturing. This happens when the machining center operator assumes that the tool will be needed later again to manufacture another type of the product on the same machine and does not take into account the fact that the tool might be needed in a different machining center.

Another necessary solution is considered in terms of the production plan optimization, through reducing the number of the tool inserting and removing operations when the workpiece production series is modified, as well as through the production plan continuous time reducing. 
In Figure 1., the production hall of the company is shown. The VTC200C machining center and the MATRIX tool warehouse are displayed on the layout, and the workpiece testing is carried out on the left-side corner as seen on the layout.

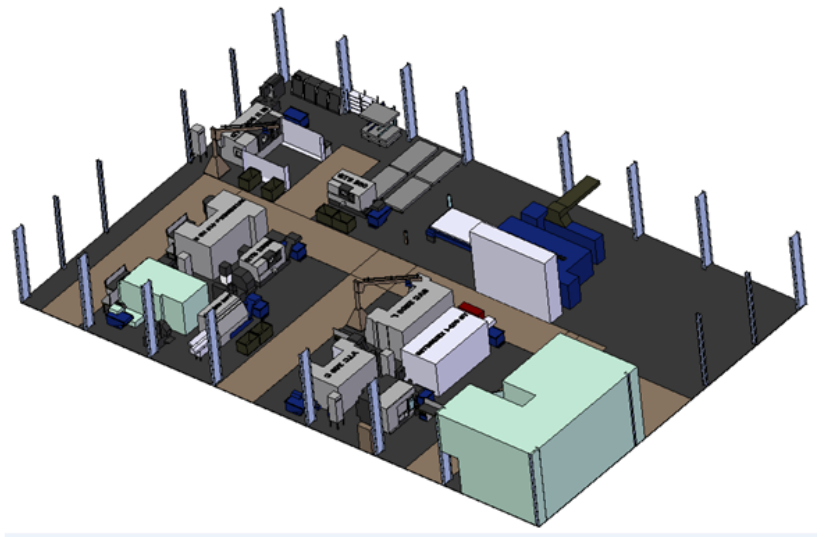

Figure 1. Layout of the company production hall

\section{The VTC200C Machine Production Process}

The manufacturing process in the VTC200C CNC machining center consists of measuring and calibration of the tools, manufacturing and modifying of the edges and checking of the workpiece dimensions. During production, the inserts of the tools are worn and their replacement is a part of the production process.

\section{The Tool Measuring and Calibration in the Tool Replacement Process During the Production Series Modification}

The tool selection and calibration represents the first basic operation required to machine the workpiece. An operator is informed about the production plan by a foreman of the production hall. At the end of the production of the previous workpiece series, the tool change process occurs. Replacement and calibration are performed by a tool fitter that has information about what tools are needed to manufacture the next workpiece. The tool fitter selects the necessary tools and chooses the inserts from MATRIX (Figure 2.). He mounts the inserts on the tool and calibrates it.

The tool has a defined position in the tool magazine. The tools are changed on the basis of the technical documentation of the individual products and inserted into the magazine together with a holder. If the previous holder and tool are different, they are replaced. In case the holder remains the same, only the tool is replaced. A lot of different cutting tools and holders are required for the series production.
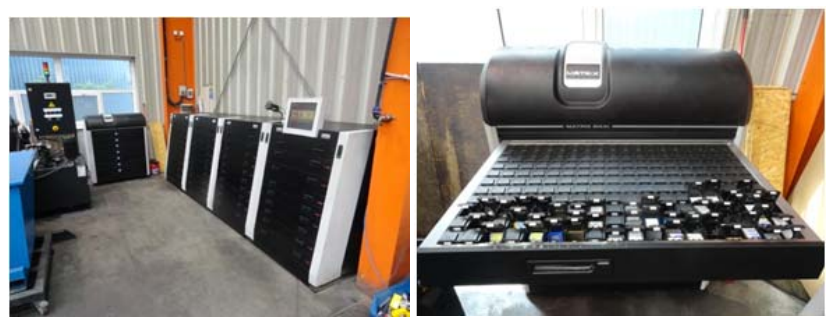

Figure 2. The MATRIX system - inserts storage

\section{Tools Used in the VTC200C Machining Center Production}

Figure 3. shows a tool sample and its technical parameters important for simulation. The technical documentation includes the name and diameter of the used tool (end mill ø16). The list of the used tools contains several tools with the same name but different technical tool parameters.

\begin{tabular}{|r|r|r|r|}
\hline Stopková fréza ø16 & ST-FREZ 16 & \multicolumn{1}{l|}{ GSXVL 4160-R10-2.5D } \\
\hline & klieština: & \multicolumn{1}{l|}{ GZB-S 20-16 PK } \\
\hline & zákl. držiak: & ISO 40 TENDO E compact \\
\hline & životnost: & $50 \mathrm{~min}$ \\
\hline & dlzka prace & $0: 01: 25$ & $\mathrm{cas} / \mathrm{ks}$ \\
\hline
\end{tabular}

Figure 3. Tool and its specifications

The tool designation (GSXVL 4160-R10-2.5D) is used to distinguish the tool accurately. The tool is inserted into a precisely designated holder (ISO 40 TENDO E compact). Some types of holders can be used for several types of tools. Tool lifespan (50min) is given in minutes and indicates whether the tool is still usable or the insert must be changed. In the technical documentation, the loss of lifespan is also stated in minutes $(1: 25 \mathrm{~min}$.) for the production of one piece of the product. These parameters are important for simulation and mapping of how often the tools get worn and how often the inserts need to be changed. Another parameter is the number of cutting edges per a tool. The inserts have several cutting edges. The average number of cutting edges per tool is 4 . The number of inserts is determined by technical documentation. These parameters are important when simulating the inserts replacement process. 
Calibration is done on the Zoller Venturion 450 measuring device. The tool is clamped into a tool holder on the measuring device and the insert size

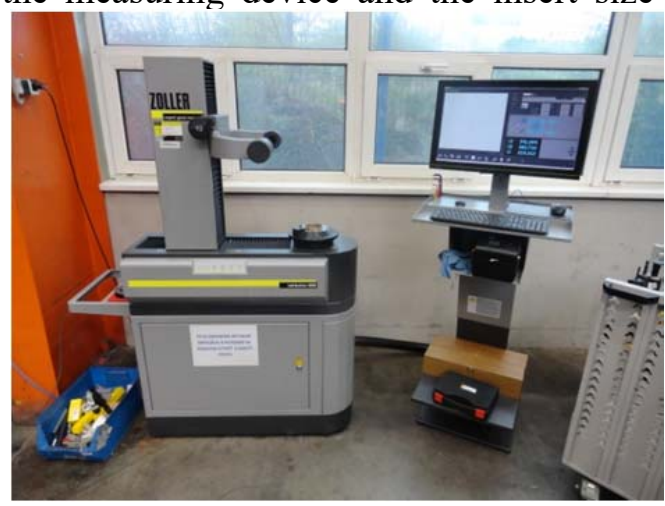

and position are measured with a probe. This measurement process is accomplished for each tool inserted into machine before production.

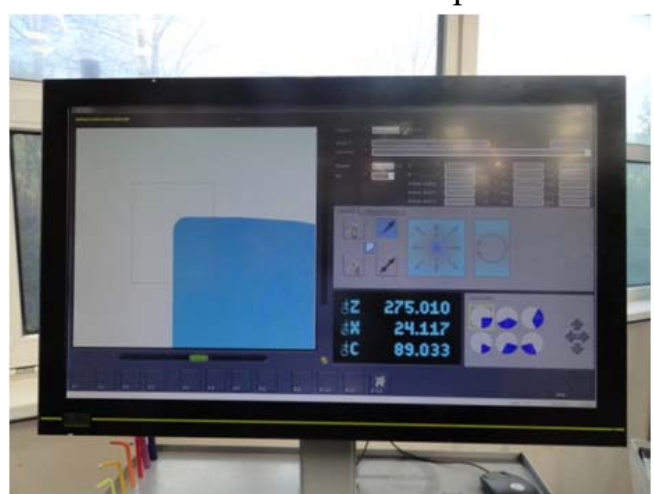

Figure 4. The Zoller Venturion 450 measuring device and the tool measuring process

\section{The VTC200C Machining Center}

The paper deals with simulation and optimization of the VTC200C measuring center production plan. The tool magazine has 29 positions and 1 position for the measuring probe. This is a 3 -axis machine with a fourth axis adding option. The machining center includes a machining chamber divided into two parts that make the production accelerate. Some workpieces must be machined from two sides. In the right part of the chamber, the upper part of the workpiece is machined, while in the second part of the chamber, the previous workpiece is machined from the other side. This process eliminates downtime caused by the door opening and closing as well as manipulation with a workpiece.
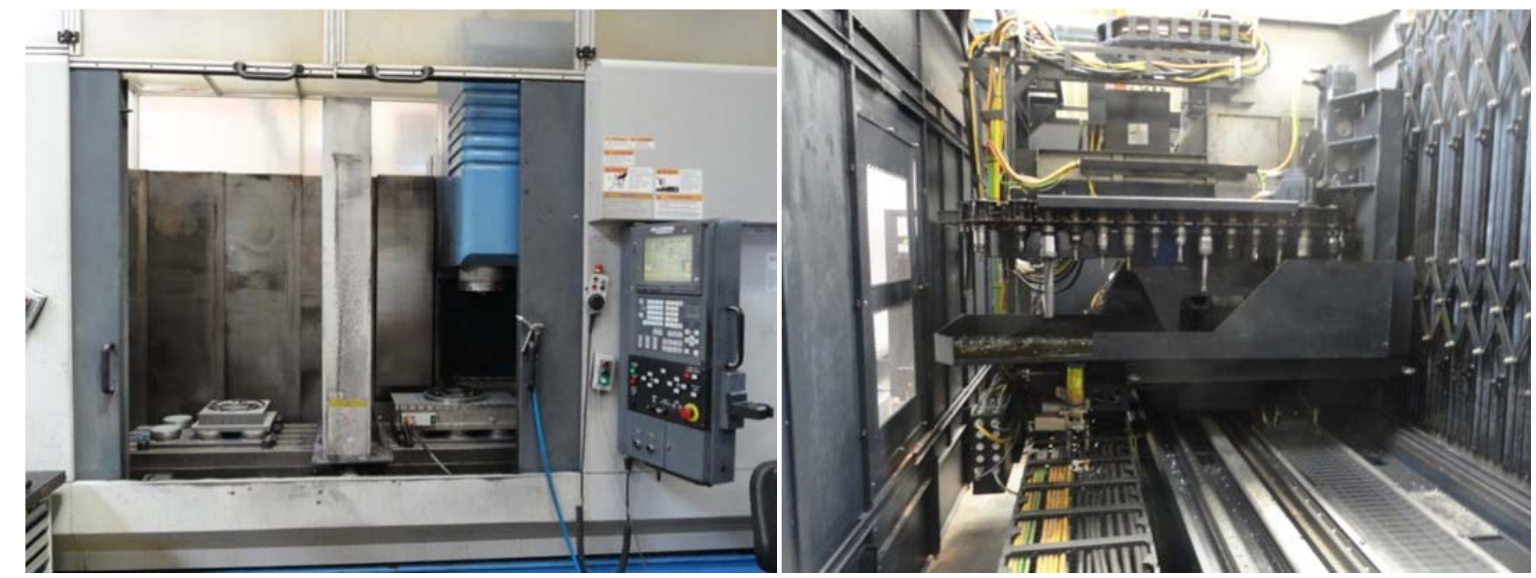

Figure 5. The VTC200C machining center and the tool magazine

Workpiece edges treatment is accomplished with the use of the hand tools. The treatment is performed by an operator while the machining center is in operation and does not need the operator's intervention. The workpieces are machined on the workbench by the operator, next to the machining center.
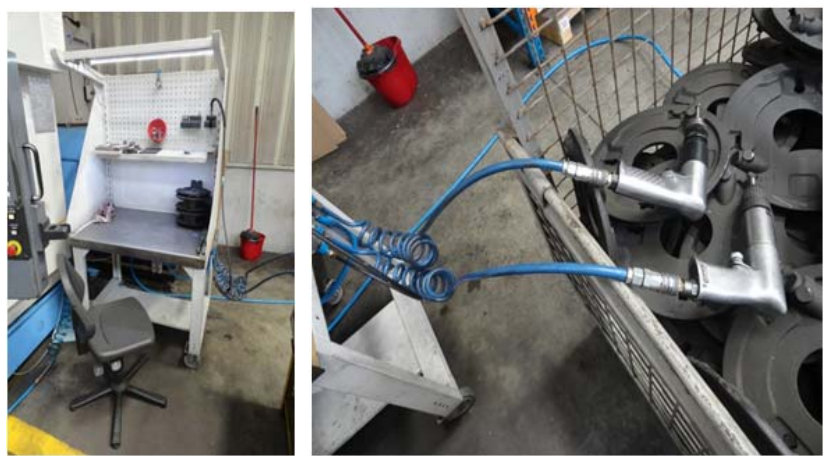

Figure 6. The workbench and the hand tools for the workpiece edges treatment 


\section{Workpiece Dimensions Control}

The workpiece dimensions control (Figure 7.) is always carried out for the first product of the series. The dimensional control is used to set up and place the workpiece correctly into a jig and it is carried out on the measuring device. Production cannot continue until the workpiece meets the defined dimensional tolerances.

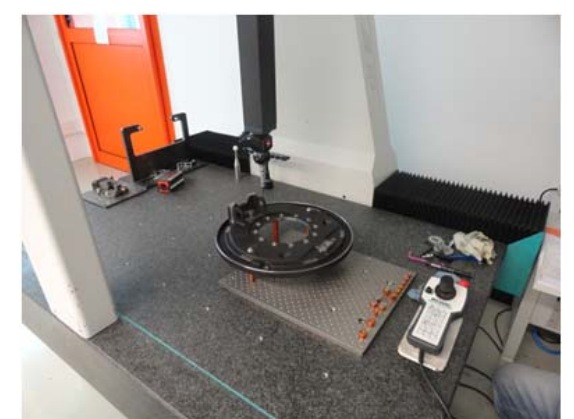

Figure 7. The Process of the workpiece dimensions control

\section{The Process of the Inserts Replacement During Manufacturing Process}

When the inserts are worn, the operator stops production in the machining center and removes the worn tool. Then he inserts the tool into a tool holder and turns each insert, provided that not all cutting edges of the insert are worn. After the inserts are turned, the inspection and measurement of the inserts must be carried out on the Zoller Venturion 450 measuring device (Figure 8.).

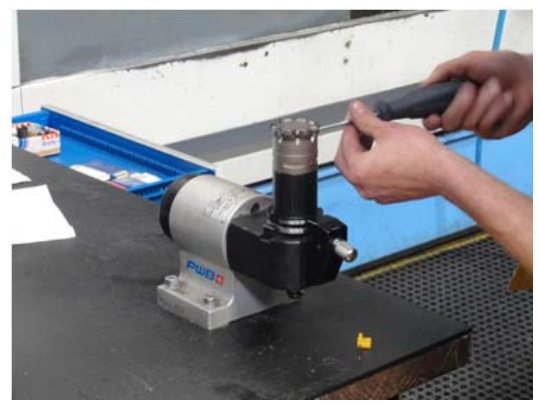

Figure 8. The insert replacement process

\section{Measurement of Process Times}

Measurement of production times was carried out during the 105911_BremStraeger (brake shield) production. Production consists of two operations. From technical documentation, it is possible to obtain the cutting times of the individual cutting tools in contact with the workpiece. This value had to be extended by a constant per tool, which was obtained from the measurement of production time and is used to create a simulation model. The production time will be extended by the calculated value.

For the simulation, we needed to sum up the production times of both operations, to eliminate the highest and lowest values and to create the average value of the production time. Subsequently, it was necessary to subtract the measured value from the value in the technical documentation and divide it by the number of tools used to produce 105911_BremStraeger. We achieved a constant that will be added to all production times in the simulation based on the number of tools used for the product.

After the measurements were realized, the average production time per product without the maximum and the minimum values were found: 1141 seconds, the value added per tool is 5.85 seconds with the use of 17 tools.

Insert exchange time values were measured during the analysis. The exchanging time of an insert had to be defined into simulation. The value was obtained by measuring and then calculated from the arithmetic mean per one insert. This simulation value is 43 seconds and is used to calculate the tool replacement time.

\section{Production Plan of the VTC200C Machining Center}

The production plan contains of 14 types of workpieces that are machined in the VTC200C machining center. The production plan is set for two weeks and contains 1842 produced pieces. The production plan and manufacturing process are determined according to Table 1. and contain different types and quantities of workpieces produced in the VTC200C machining center. The production plan contains more complex workpieces with long production times, but also simpler workpieces with shorter production times. 
Table 1. The production plan and manufacturing process

\begin{tabular}{|c|l|c|}
\hline Code & Workpiece name & Quantity [pcs] \\
\hline 105911.01 & Brake shield 250x60 hydr.servo reinforced & 200 \\
\hline 105911.02 & Brake shield 250x60 hydr.servo reinforced & 200 \\
\hline 203108.001 & Stop plate KHD35 & 10 \\
\hline 706520.001 & Plate KHD27-35 150x35x12 & 200 \\
\hline 709100.001 & Plate 135x35x12 & 40 \\
\hline 721299.001 & Drawbar plate 265x60/20 VIKING & 2 \\
\hline 721910.001 & Wheel pinn with lever o55 / 35 M30 left mach. VIKING & 6 \\
\hline 722081.001 & Drawbar holder 184x55 mach. VIKING & 50 \\
\hline 725447.002 & Plate P, ZETOR 16.342.006 bl. & 3 \\
\hline 725873.001 & Wheel pinn with lever o55/40 M36 left mach. VIKING 5000kg & 3 \\
\hline 725873.002 & Wheel pinn with lever o55/40 M36 right mach. VIKING 5000kg & 120 \\
\hline 0124.03 & Brake shield 400x80 hydr.servo & 700 \\
\hline 106197 & Disc brake lining carrier HGS 2x48 & 300 \\
\hline 25999 & Brake shield weld. 200x30 Hydr.-Simplex o77 mach. & \\
\hline
\end{tabular}

\section{Parametric Simulation Model of the VTC200C Machining Center Development in the Plant Simulation Environment}

The parametric simulation model is created in the Plant Simulation environment. Plant Simulation is a program used to develop material flow, production lines and warehouses simulations, but it may create different types of simulations in the production process [4], [5]. The simulation will not cover the production line but will refer to the production process in one machining center and the tool movement within it.

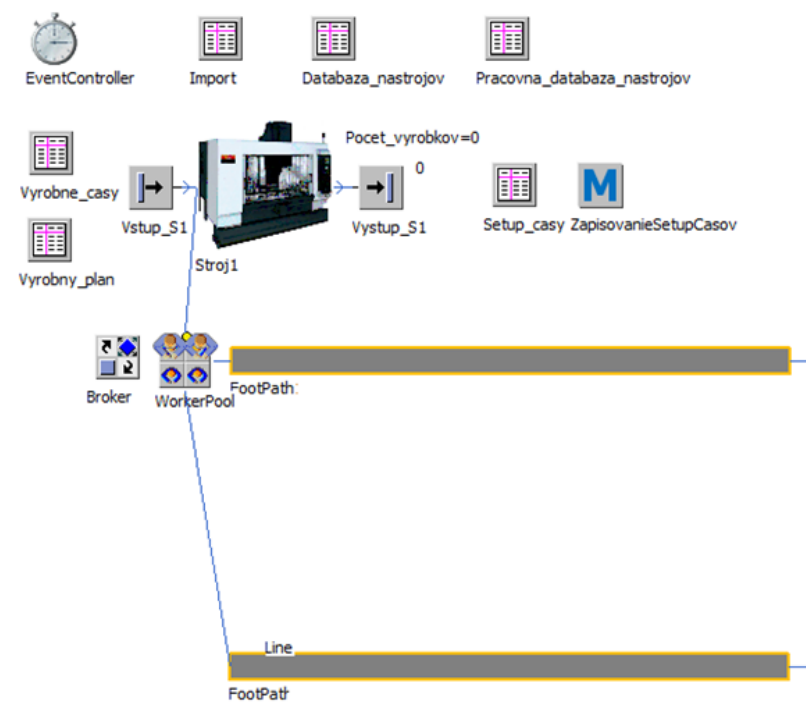

Figure 9. Simulation model layout in Plant Simulation environment
The parametric model is created with the possibility of future extension and adding several machining centers to the simulation and covering the whole production hall [3]. This extension would serve to map the material flow of the production hall and the working staff usage. The advantage of the parametric model lies in the possibility of changing the baseline values without changing the algorithm. Figure 9. shows a schematic diagram of a simulation model of the VTC200C machining center.
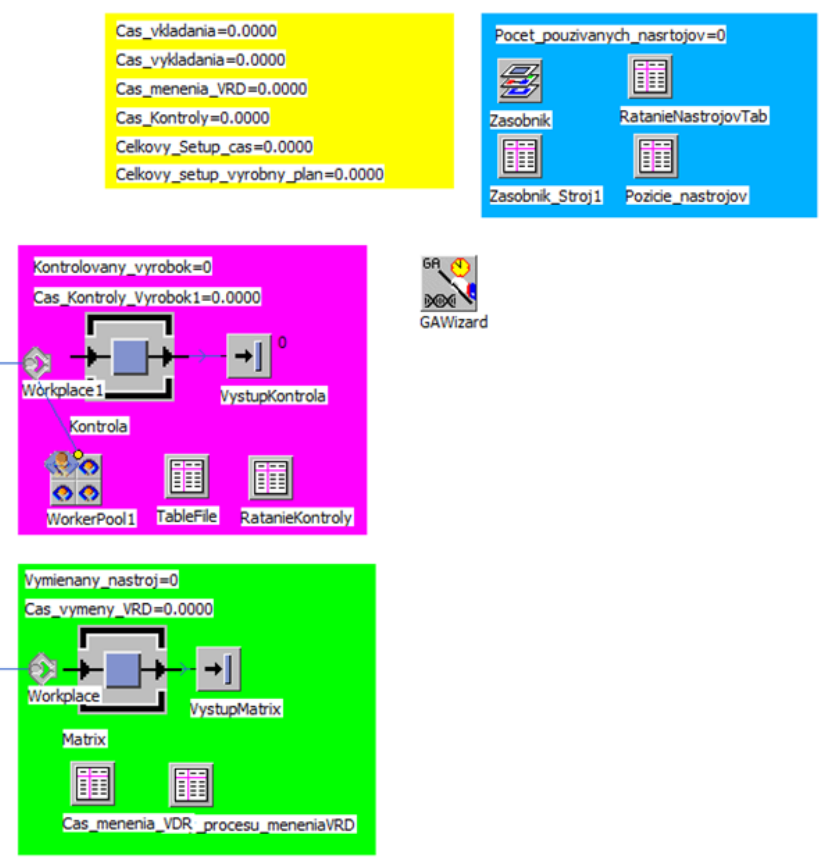

Kontrolowany wrobok=0

TorkerPool1 Tablefile RatanieKontroly 
Before a detailed description of the program and its functionality, the simulation and setup of the production staff and the "Zasobnik_Stroj1" object should be described.

\section{Production Staff Objects}

In Plant Simulation, a group of objects is used to simulate workers:

- WorkerPool, a place that represents inactive and available workers,
- Worker, an object that represents a worker,

- Broker, an object used to manage workers on the basis of their competence.

Workers are divided into two WorkerPool groups. An Operator and an Adjuster are located in the WorkerPool object, and an Observer is located in the WorkerPool1 object. These properties are set in the Worker settings, on the Attributes card in the Services window. The individual competencies of the workers are shown in Figure 10.

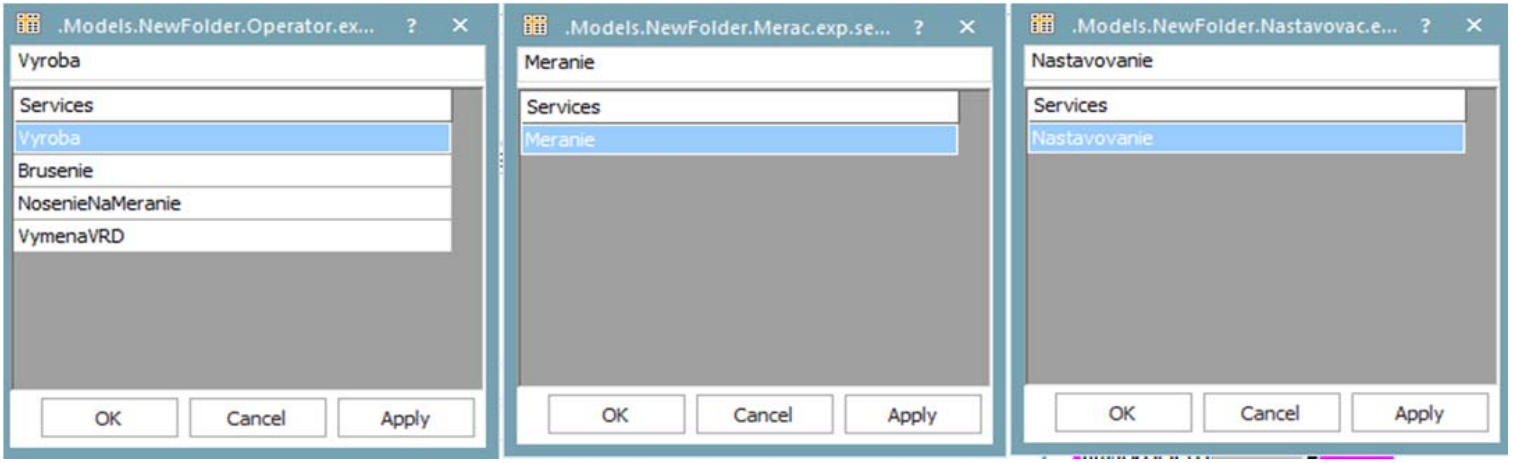

Figure 10. Competencies of employees A) Operator

B) Observer C) Adjuster in the simulation model

\section{3. “Zasobnik_Stroj1” object}

The Zasobnik_Stroj1 object represents the machining tool magazine and provides work data obtained from the input databases for individual tools and manufacturing operations. The Zasobnik_Stroj1 object is designed in the form of a 30-row table of which 29 rows represent the positions in the VTC200C machining center tool magazine. The last position is intended for the probe and is not considered in the simulation.

Data contained in the Zasobnik_Stroj1 object:

- position in the tool magazine (serial number in the VTC200C machining center tool magazine),

- tool name (name of an individual tool stored in the given position),

- tool designation (detailed tool characteristics),

- tool holder (the tool holder name),

- number of cutting edges on the insert,

- maximum tool lifespan [s],

- current tool lifespan [s],

- tool lifespan percentage [\%],

- tool change $\mathrm{T} / \mathrm{F}$ (the value that indicates the simulation when the tool lifespan falls below critical value and the insert replacement is required),

- number of inserts per tool,

- tool replacement time [min],

- tool holder replacement time [min],

- length of work [min] (tool time per workpiece)

- use of the tool (True / False signals the use of the tool for the current workpiece).

\section{Description of the Simulation Model Functionality}

The simulation model is parametric, which implies that the simulation is based on input data defined in excel files. This data contains information from the technical documentation provided by the company and contains the information such as tools needed for individual products, production times, tool parameters, etc. Some values are defined directly in the model and are needed to run the simulation correctly. Functionality and detailed information about these objects and data will be described in the following section of the paper.

\section{Preparing the Input Data for Simulation}

The first step in the simulation is performed by importing an Excel file into the Plant Simulation environment. The function of the Import object in a table form is to link the .xls (Excel) files containing all information about the tools, tool parameters, and their application to produce workpieces. The Import advantage refers to clear and easy manipulation with input tool database for simulation, in the form of .xls table. An example of the imported data is in Figure 11.

The table contains the following information:

- tool name,

- tool designation,

- tool holder,

- tool position in a magazine, 
- number of cutting edges of inserts,

- maximum tool lifespan,

- number of tool inserts,

- replacement time,

- replacement time of tool with holder,

- tool cutting times for individual workpieces.

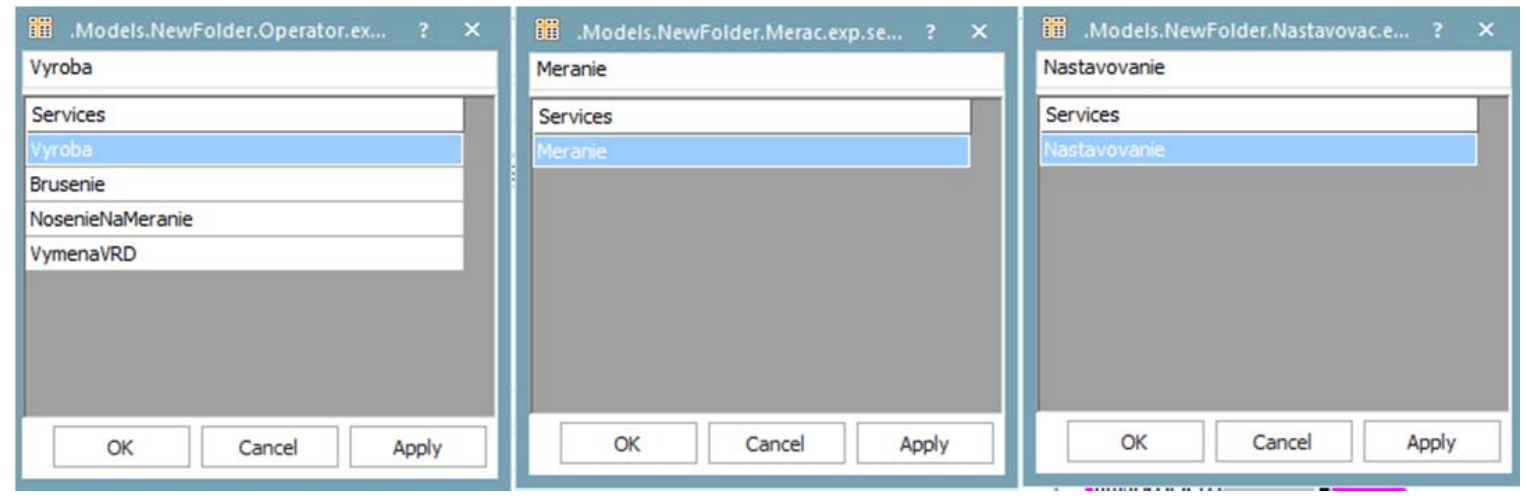

Figure 11. Imported Excel data into Plant Simulation environment

The next step of the Method_Init is to fill in the table in the Databaza_nastrojov object. The Databaza_nastrojov represents a static database with the same values as in the Import and provides a basic overview of the tools and their application. It is created in the Pracovna_Databaza_nastrojov object in the form of a table. It is used to record the current tool lifespan and the number of cutting edges available on all tools. Along with creating the input databases, Methoda_Init is designed to prepare the Vyrobne_casy object for basic values from the technical documentation. This operation is needed to change the production time values during the simulation by added constants and to adjust the values to the real product production time values.

The last Method_Init operation is to set the Zasobnik object to its initial values. The Zasobnik object is a SubFrame of the simulation model and represents the VTC200C machine magazine.

\section{Simulation of the Manufacturing Process in the VTC200C Machining Center}

This part of the paper describes the simulated production process and all operations and objects necessary to perform this process.

The manufacturing process in the VTC200C machining center consists of several operations:

- inserting and removing the tools required for production,

- production,

- manual treatment of edges,

- checking the product dimensions,

- inserts replacement process.

The simulation model contains several auxiliary operations and objects needed to create the simulation model, although these operations are not performed and are not the main elements of the simulation nowadays.

In the next part of the paper, considering the scope of the solution, we focus on clarifying some of the activities and the achieved results.

\section{Simulation of the Tool Replacement Process in the Simulation Model}

The tool replacement process begins with switching of the Pouzivanie_nastroja value for all tools clamped in the Zasobnik_Stroj1 to False. In case of the first product of the production plan, this operation will not be performed.

Subsequently, four counters used to collect data from the production process simulation will be set to zero. These are the Variable objects. In the Value card and in the Data type options, the time option is selected and the initial value is set to 0 .

Cas_vkladania - time of inserting one tool into the magazine,

Cas_vykladania - time of removing one tool from the magazine,

Cas_menenia_VRD - worn insert replacement time,

Celkovy_Setup_cas - total downtimes duration calculated per product series.

Data is recorded over the production series. When the series is changed, the values are saved into a table in the Setup_Casy object, to provide an overview of downtimes during production.

The following process works with the Pracovna_databaza_nastrojov database and the Zasobnik_Stroj1 object. Browsing in the Pracovna_databaza_nastrojov is performed by combining the defined Dlzka_Prace_ constant and 
the entity name from Figure 12 a). Together they create the name: Dlzka_Prace_Bremstraeger_105911_01. Based on this name, the program selects the necessary tool for the product if its value is non-zero. Figure 13. shows a column of the work time values for the Bremstraeger_105911_01 product.

Typ_vyrobku=0

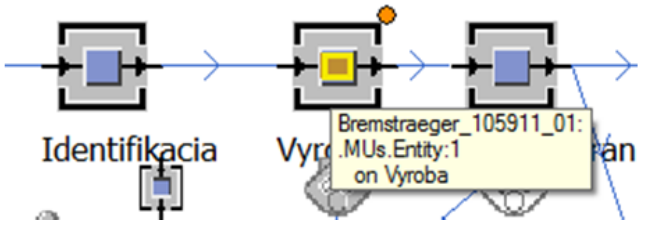

Typ_vyrobku=Bremstraeger_105911_01

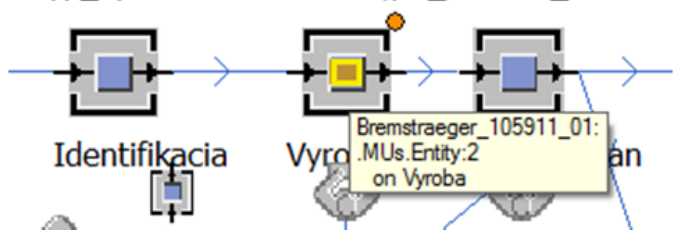

Figure 12. a) Different entity names b) Same entity names

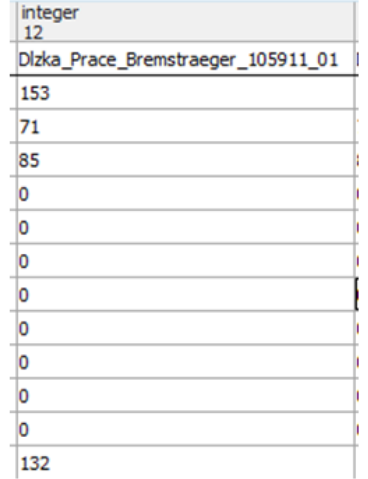

Figure 13. Work time values column for Bremstraeger_105911_01

After finding the necessary tool, the program copies all the relevant data from the Pracovna databaza_nastrojov object to the Zasobnik_Stroj1 object. The algorithm records the tool data to a defined row representing the magazine position. The tools required for the production series are entered in the Zasobnik_Stroj1 object. When entering data to the Zasobnik_Stroj1 object, all newly inserted or corrected tools are set to True in the Pouzivanie_nastroja column. The False value remains for the unused production series tools and indicates that the tool is not used for the current production series (Figure 14.).

\begin{tabular}{|c|c|c|c|c|c|c|c|c|c|c|c|c|c|}
\hline & $\begin{array}{l}\text { string } \\
2\end{array}$ & $\begin{array}{l}\text { string } \\
3\end{array}$ & $\begin{array}{l}\text { string } \\
4\end{array}$ & $\begin{array}{l}\text { integer } \\
5\end{array}$ & $\begin{array}{l}\text { integer } \\
6\end{array}$ & $\begin{array}{l}\text { integer } \\
7\end{array}$ & $\begin{array}{l}\text { integer } \\
8\end{array}$ & $\begin{array}{l}\text { boolean } \\
9\end{array}$ & $\begin{array}{l}\text { integer } \\
10\end{array}$ & $\begin{array}{l}\text { time } \\
11\end{array}$ & $\begin{array}{l}\text { time } \\
12\end{array}$ & $\begin{array}{l}\text { integer } \\
13\end{array}$ & $\begin{array}{l}\text { boolean } \\
14\end{array}$ \\
\hline string & Nazov_nastroja & Oznacenie_nastroja & Drziak_nastroja & Rezne_hrany__VRD & Maximaha_ziv... & Aktuaha_zivotnost & Percentualna_zivotrost & Vymena_Nastroja_T/F & Pocet__VR & Vymena_na... & Vymena_... & Dlzka_Prace & Pouzivanie_Nastroja \\
\hline 1 & Stopkovà fréza 054 & C5-R217.96-054-08-4A & C5-390-140-40-070 & 4 & 2400 & 2247 & 93 & false & 8 & $2: 00.0000$ & 5:00.0000 & 153 & true \\
\hline 2 & Čehả fréza 063 & $R 220.43-0063-075 \mathrm{~A}$ & E346955252235 & 4 & 3000 & 2929 & 97 & false & 8 & 2:00.0000 & 5:00.0000 & 71 & true \\
\hline 3 & Stopková fréza ه10 & $05573-10,0$ WN3142 10... & ISO 40 TENDOE EO... & 4 & 2400 & 2363 & 98 & false & 2 & 2:00.0000 & 5:00.0000 & 37 & true \\
\hline 4 & Uhlová fréza o 20 & SCP $308\left(90^{\circ} 08-20,1 \mathrm{~m} \ldots\right.$ & E3469584222035 & 4 & 3000 & 2974 & 99 & false & 1 & 2:00.0000 & 5:00.0000 & 26 & true \\
\hline 5 & Stopková fréza 016 & GSXVL 4160R R10-2.5D & ISO 40 TENDO E CO... & 4 & 3000 & 2915 & 97 & false & 4 & 2:00.0000 & 5:00.0000 & 85 & true \\
\hline 6 & Stopková fréza ø16 & $316-16 \mathrm{HM} 450 \mathrm{C} 16020 \mathrm{P} 1 \ldots$ & 392.140 EH-40 16049 & 4 & 2400 & 2344 & 97 & false & 4 & $2: 00.0000$ & 5:00.0000 & 56 & true \\
\hline 7 & M5 Závitnik & C4-125551-0050 & ISO 40 TENDO E CO... & 4 & 1800 & 1785 & 99 & false & 1 & $2: 00.0000$ & $5: 00.0000$ & 15 & true \\
\hline 8 & Uhlová fréza o 35 & $\operatorname{SCP} 419\left(90^{\circ} \circ 19-35,6 \ldots\right.$ & E3469584222035 & 4 & 3000 & 2895 & 96 & false & 3 & $2: 00.0000$ & 5:00.0000 & 105 & toue \\
\hline 9 & Vrtak 1650030 VRD & WDX 165 D3 S20 & WDXT 052504L. AC... & 4 & 2400 & 2345 & 97 & false & 2 & 2:00.0000 & 5:00.0000 & 55 & true \\
\hline \multicolumn{14}{|l|}{10} \\
\hline 11 & Vrták 1300030 VRD & WDX 130 D 3 S20 & WDXT 042004L. AC... & 4 & 2400 & 2384 & 99 & false & 2 & 2:00.0000 & 5:00.0000 & 16 & tue \\
\hline \multicolumn{14}{|l|}{12} \\
\hline \multicolumn{14}{|l|}{13} \\
\hline 14 & Stopková fréza 020 & WEX $1020 E$ & ISO 40 TENDO E CO... & 4 & 3000 & 2855 & 95 & false & 7 & 2:00.0000 & 5:00.0000 & 145 & true \\
\hline 15 & Vrták $06.30050 \mathrm{~V} . .$. & SOP 0630 U 5 HAK ACX70 & ISO 40 TENDO E CO... & 4 & 1800 & 1784 & 99 & false & 2 & 2:00.0000 & 5:00.0000 & 16 & true \\
\hline 16 & Vrták $15.20050 \mathrm{~V} . .$. & $05511-15,200$ DIN653 & ISO 40 TENDO E CO... & 4 & 2400 & 2376 & 99 & false & 2 & 2:00.0000 & 5:00.0000 & 24 & true \\
\hline \multicolumn{14}{|l|}{17} \\
\hline \multicolumn{14}{|l|}{18} \\
\hline \multicolumn{14}{|l|}{19} \\
\hline 20 & Stopková fréza $₫ 25$ & R217.96-1225.RE-04-5A & SECO E3476 $58211 \ldots$ & 4 & 2400 & 2268 & 94 & false & 3 & $2: 00.0000$ & $5: 00.0000$ & 132 & tue \\
\hline 21 & Uhlová fréza o $16 \ldots$ & . $316-16 C \mathrm{C} 800-1604561 \ldots$ & SANDVIK $392.140 E . .$. & 4 & 6000 & 5970 & 99 & false & 4 & 2:00.0000 & 5:00.0000 & 30 & true \\
\hline \multicolumn{14}{|l|}{22} \\
\hline \multicolumn{14}{|l|}{23} \\
\hline 24 & Stopková fréza ๑50 & $R 220.29-0050-04.5 \mathrm{~A}$ & ISO 40 TENDO E CO... & 4 & 3600 & 3540 & 98 & false & 6 & 2:00.0000 & 5:00.0000 & 60 & true \\
\hline \multicolumn{14}{|l|}{25} \\
\hline \multicolumn{14}{|l|}{26} \\
\hline \multicolumn{14}{|l|}{27} \\
\hline \multicolumn{14}{|l|}{28} \\
\hline 29 & Vrták $04.20050 \mathrm{~V} . .$. & SDP 0420 U 5 HAK ACX70 & ISO40 TENDO E CO... & 4 & 1800 & 1734 & 99 & false & 2 & $2: 00.0000$ & $5: 00.0000$ & 16 & true \\
\hline
\end{tabular}

Figure 14. Zasobnik_Stroj1 object sample 


\section{Graphic Indication of the Machine Magazine}

The next step of the program is to run the Spustanie_nastrojov method. This method controls the SubFrame object named as Zasobnik and is used as a graphic representation of the tool magazine. There are 30 positions in the Zasobnik object (Figure 14.), 29 of which are those for cutting tools and 1 position is for the probe. For each tool position, the signalling changes are, as follows:

The cutting tool is fixed in a position and is used in the manufacturing process.

The cutting tool is fixed in a position but is not used in the manufacturing process.

There is no cutting tool in the magazine position.

The positions in the magazine are named as N1-29.
When the cutting tool is inserted into the magazine position, the cutting tool label, as well as the fact whether it is used with the current product, are automatically displayed. The Zasobnik object is created with the use of 30 SingleProcs, by which the object icons including 30 Variable objects are changed according to signals, and where the name of the tool stored in the given position is entered. The Spustanie_nastrojov method works with the object in the form of the Pozicie_nastrojov table, which is shown in Figure 15. The first column Pozícia, represents the numeric identification of the location in the magazine. The Signalizacia and Oznacenie_nastroja columns have the object character. There are SingleProc objects involved in the Signalizacia column and variable objects in the Oznacenie_nastroja column.

\begin{tabular}{|c|c|c|c|}
\hline & $\begin{array}{l}\text { integer } \\
1\end{array}$ & $\begin{array}{l}\text { object } \\
2\end{array}$ & $\begin{array}{l}\text { object } \\
3\end{array}$ \\
\hline string & Pozicia & Signalizacia & Oznacneie_nastroja \\
\hline 1 & 1 & Models.Frame.Zasobnik.Poz1 & .Models.Frame.Zasobnik.N1 \\
\hline 2 & 2 & Models.Frame.Zasobnik.Pozz & Models.Frame.Zasobnik.N2 \\
\hline 3 & 3 & Models.Frame.Zasobnik.Poz3 & Models.Frame.Zasobnik.N3 \\
\hline 4 & 4 & Models.Frame.Zasobnik.Poz4 & Models.Frame.Zasobnik.N4 \\
\hline 5 & 5 & Models.Frame.Zasobnik.Poz5 & Models.Frame.Zasobnik.N5 \\
\hline 6 & 6 & Models.Frame.Zasobnik.Poz6 & .Models.Frame.Zasobnik.N6 \\
\hline 7 & 7 & Models.Frame.Zasobnik.Poz7 & Models.Frame.Zasobnik.N7 \\
\hline 8 & 8 & Models.Frame.Zasobnik.Poz8 & Models.Frame.Zasobnik.N8 \\
\hline 9 & 9 & Models.Frame.Zasobnik.Poz9 & Models.Frame.Zasobnik.N9 \\
\hline 10 & 10 & Models.Frame.Zasobnik.poz 10 & Models.Frame.Zasobnik.N10 \\
\hline
\end{tabular}

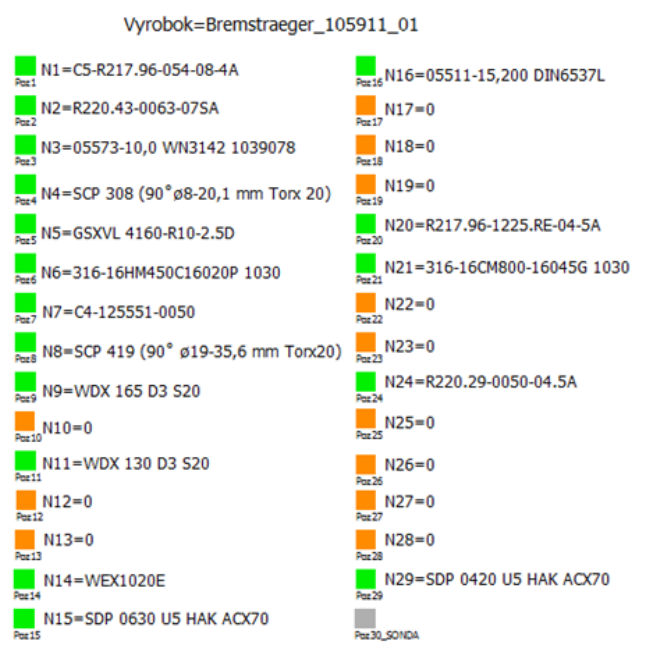

Figure 15. The Pozicie_nastrojov and Zasobnik objects in the Bremstraeger production

\section{Production Plan Optimization}

The production process simulation model in the VTC200C machining center provided data to optimize the production plan ordered by the selected company. The optimization is performed using the GAWizard element. GAWizard works on the basis of genetic algorithm [6]. Based on the outputs from the simulation model, the optimization of the production plan was created based on reducing downtimes during the change of the production series. Optimization aims to find the optimum production plan in terms of the tool replacement in order to make it more efficient.

We set the Optimazation direction to find the maximum or minimum of the optimized value. In our case, the minimum is chosen. Other parameters are Number of generations and Size of generation. These are parameters indicating the accuracy of the results of the genetic algorithm.
The Optimization parameter determines the parameters that the algorithm will work with. The optimized value is entered in the Fitness calculation section and Celkovy_setup_vyrobny_plan is selected. The genetic algorithm was set to 10 generations with the size of 30 calculations, these values were selected in order to achieve the best result. The algorithm found the optimal value in the 5 th generation and interrupted the subsequent recalculation of the options.

\section{Solution Results}

Based on input data, GAWizard has optimized the production plan. In Figure 16 a, the production plan with the original and new sequence of products is shown. With the new sequence in the production plan, the Celkovy_setup_vyrobny_plan value was reduced to 2 days $11 \mathrm{~h} 37 \mathrm{~min}$ and 12 seconds (Figure $16 \mathrm{~b})$. 


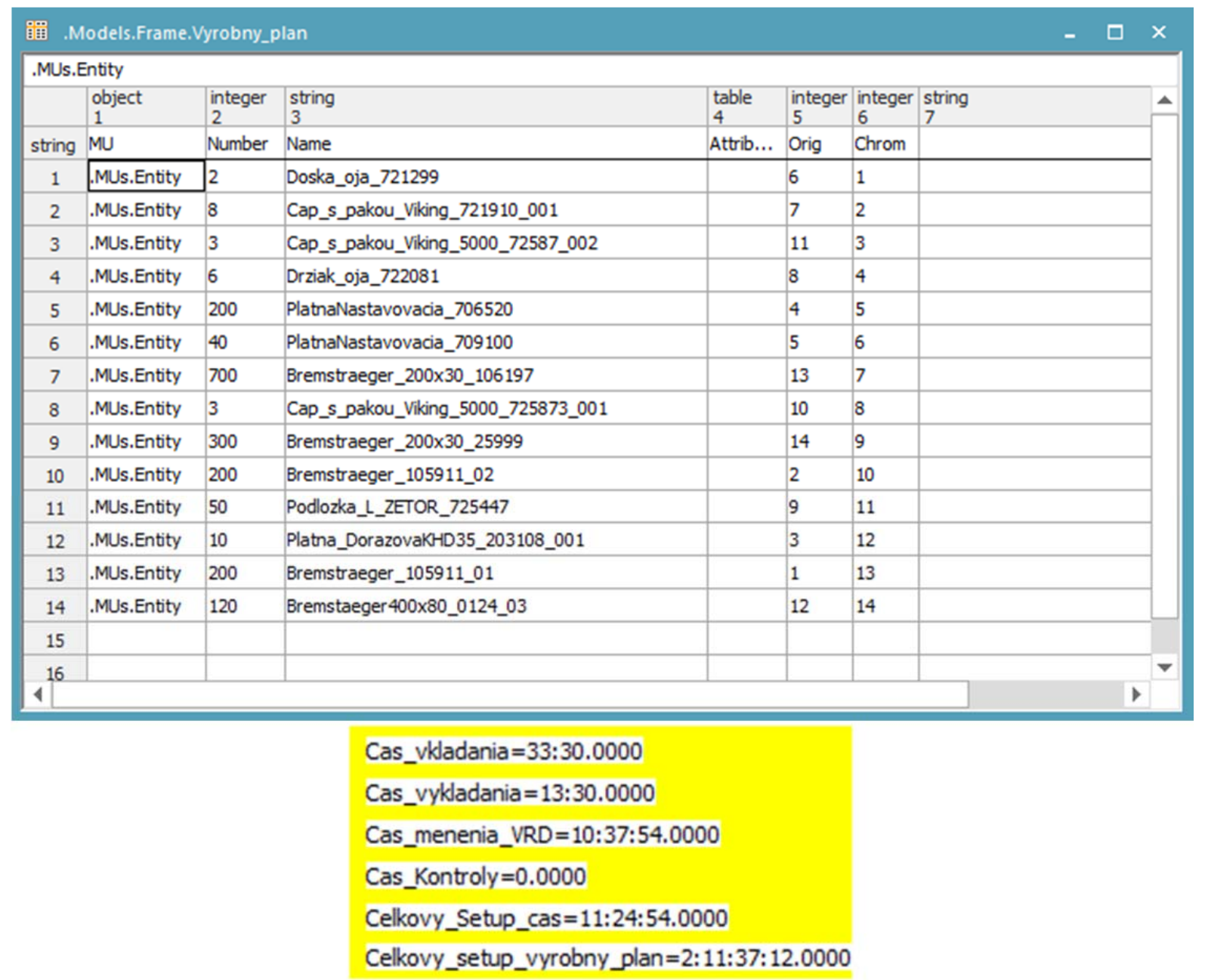

Figure 16. Optimized production plan and downtimes in a new production plan

By the production plan optimatization, the production downtimes were reduced by $\mathbf{4 0}$ minutes and 46 seconds. The optimization was based on the change in the production plan product order to increase the replacement efficiency of the clamped and inserted tools into the VTC200C machining center magazine.

HTML report can be created by the GAWizard element. The report contains information about the simulation model, when the optimization was performed, about the length and the result of the optimization. The report also contains two informative graphs.

The graph in Figure 17. shows the best, average and worst results in a particular generation. Time values are displayed on the $\mathrm{Y}$-axis and the number of generations is shown on the $\mathrm{X}$-axis. The graph indicates a gradual search for a better optimized parameter. In the first generation, the highest values for the optimized parameter are shown. In the (last) final generation, the curve has a non-decreasing character and indicates finding a minimum value of the optimized parameter.
In Figure 18., a graph shows all values calculated by the genetic algorithm. The graph provides the highest and lowest result values.

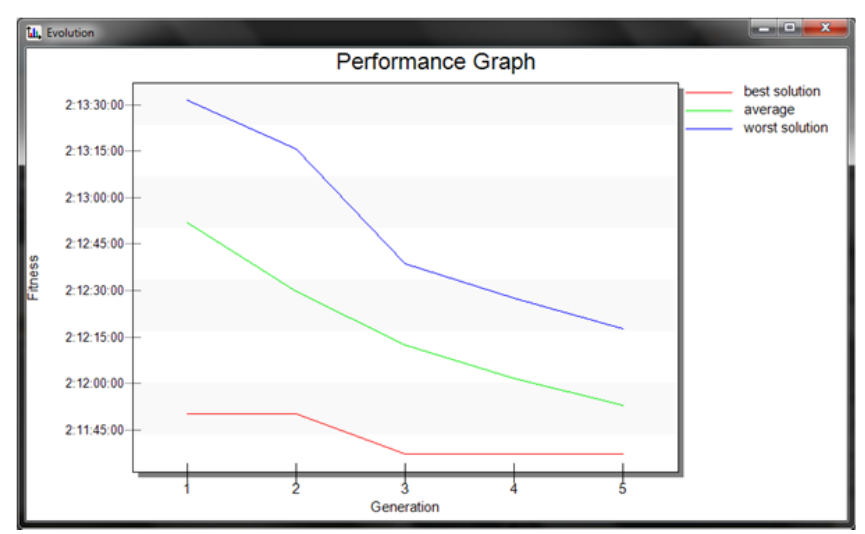

Figure 17. Graph of searching the minimum value in the genetic algorithm 


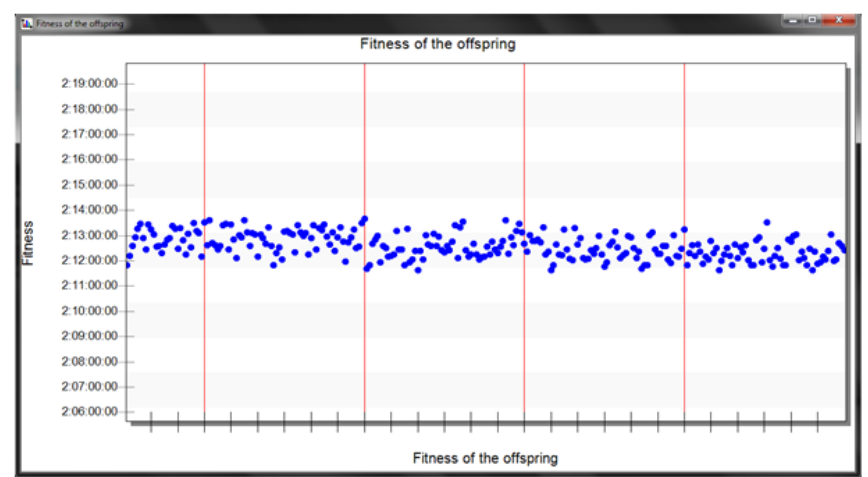

Figure18. Graph of all values calculated during the genetic algorithm

Reduction in time spent by the operator's walking during the insert replacement process was also achieved. Once optimized, more tools are worn-down at the same time. This ensures more efficient inserts replacement. Several tools are replaced by the operator at the same time, thus saving the walking time of the operator to the workplace. The operator's statistical values are shown in Figure 19. upper. With the original production plan, the operator is working at $98.01 \%$ of the total production time and is walking a distance of 30102 meters. In Figure 19. lower, changed values can be seen after optimization when the operator is working at $98,18 \%$ of the total production time and the walking distance is reduced to 26883 meters.
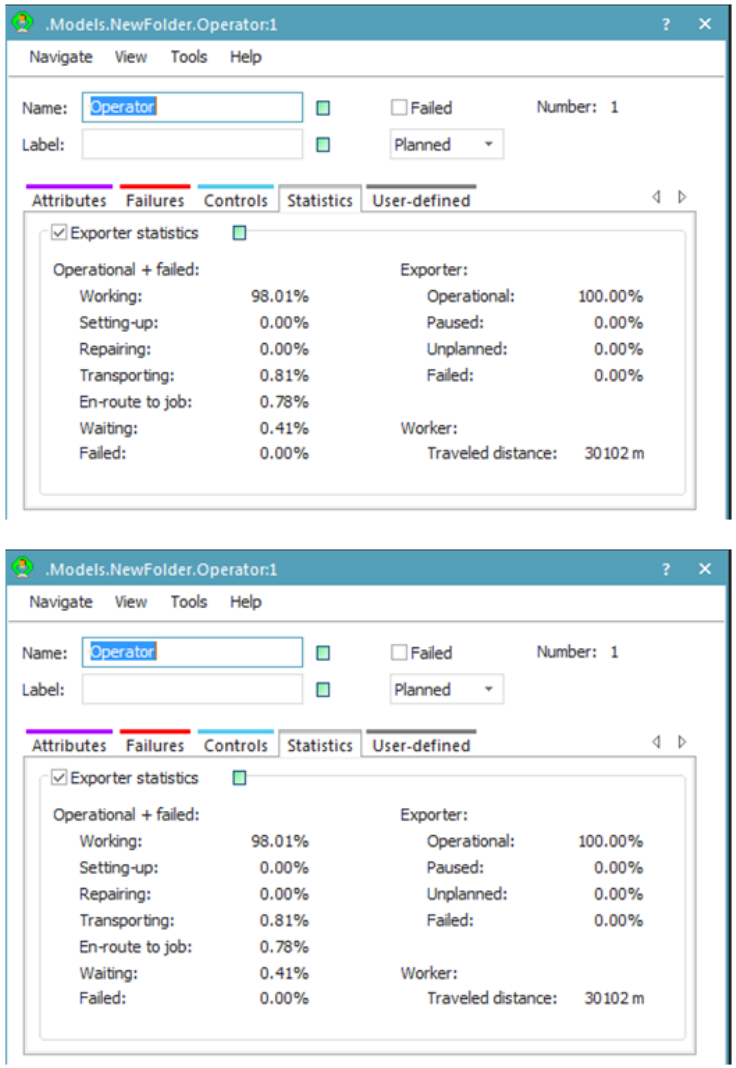

Figure 19. Operator statistics before and after optimization

\section{Conclusions}

The paper describes the design of the parametric simulation model in the Plant Simulation environment, which was used to optimize the production plan in the VTC200C machining center. Several simulation model variants were created over the simulation and, based on the presentation in a company, the final version of the simulation model was selected [9]. The initial proposal included a simple simulation of the VTC200C machining center, but after consulting it with the company, other workplaces and processes related to the production process were added.

The simulation model helped reduce the production time of the workpiece series by 40 minutes and 46 seconds. This value can be achieved without intervention into the production process. The change would be done through modification in the production plan product order. The simulation model has the potential to be extended by next production machines and thus create a simulation model of the whole production hall and increase coordination efficiency between all machines. The company plans to start using simulation and optimization programs. The paper also serves as a demonstration of options of the Plant Simulation program application for the company, as well as of its use to improve the production process efficiency without major investments [10]. The simulation also brought shortening of the walking distance of the worker and streamlining of the insert replacement process. The GAWizard element with the use of learning algorithm was applied for optimization. The genetic algorithm used the simulation results as input data. Based on the data, the products order in the production plan was optimized without major interventions into production.

\section{Acknowledgement}

This paper was created with support of the Cultural and Educational Grant Agency of the Ministry of Education, Youth and Sports of the Slovak Republic under the KEGA 027STU-4/2019 contract. 


\section{References}

[1]. Jerz, V. (2008). Simulácia a optimalizácia výrobných systémov. In Slovak University of Technology in Bratislava, 128 s. ISBN: 978-80-89313-16-7.

[2]. Lazar, D. (2016). Optimalizácia výroby dverových obkladov v IAC Group (Slovakia), s. r. o., s využitím simulácie. Slovak University of Technology in Bratislava

[3]. Jašurek, J. (2010). Simulácia výrobného systému vo firme Muhlbauer. Slovak University of Technology in Bratislava

[4]. Malega, P (2015): Možnosti simulácie výroby v Plant Simulation. In: The 18th International Scientific Conference Trends and Innovative Approaches in Business Processes “2015”, ISBN 978-80-553-22551

[5]. SIEMENS (2019). Tecnomatix - Plant Simulation. Copyright (C) 2018 Siemens Product Lifecycle Management Softwar.e Retrieved from: https://www.plm.automation.siemens.com/global/en/p roducts/manufacturing-planning/plant-simulationthroughput-optimization.html [accessed: 07 May 2020].
[6]. Němec, J. (2016). Effectiveness of Evolutionary Algorithms, Brno University of Technology. Retrieved from:

https://www.vutbr.cz/www base/zav prace soubor v erejne.php?file id=126810. [accessed: 20 May 2020].

[7]. Sekaj, I. (2004). Riešenie problémov pomocou genetických algoritmov. Automatizace, 47(9), 552555 .

[8]. Mitchell, M. (1998). An introduction to genetic algorithms. MIT press.

[9]. Bako, B., \& Božek, P. (2016). Trends in simulation and planning of manufacturing companies. Procedia Engineering, 149, 571-575.

[10]. Bozek, P., Knazík, M., \& Stollmann, V. (2014). Modern Planning and Control and Virtual Verification of Process Continuity of a New Production Line. Applied Mechanics and Materials, 708, 167. 